\title{
An Analysis of the Traditional Religious Thought and its Impact on Poverty: A Case Study of the Amansie Traditional Area, Ashanti Region, Ghana
}

\author{
Charles Owusu Ampofo' \\ 1 Department of Religious Studies, Kwame Nkrumah University of Science and Technology, Kumasi Ghana.
}

\begin{abstract}
It is important to stress that, the Akan amongst many other cultures in Africa by their beliefs and practices, emphasize the individual and the societal wellbeing. Primarily, their idea of wholeness is seen to have been focused on mostly the material and spiritual needs of the human; that is, the complete satisfaction of all members of the community. The people of Amansie West Traditional Area, therefore, view poverty as undesirable and is frowned upon by society. However, the communities should help ease the stress and trauma of the poor. Such insight conforms with an old adage, wo yonko da ne wo da, which could in a way be literary translated as, "A friend in need is a friend indeed." It is essential, then, to probe into the relationship that ever existed between the religio-cultural thoughts on poverty and the perceptible impact of poverty on the living conditions of the people in Amansie. The study consequently applied both qualitative and quantitative methods to extract relevant data from respondents. Semi-structured questionnaires were administered to relevant persons; an interview guide was developed to facilitate the personal interviews conducted with traditional leaders, townsfolks, religious leaders, opinion leaders, and other stakeholders. The findings among others were that poverty has a religio-cultural dimension; it is a spiritual and moral misfortune. The study recommends a Religio-Cultural Renaissance as a possible avenue to resuscitate and strengthen what otherwise looks like a dearth of religio-cultural practices of the community. A collaborative effort is therefore required by religious leaders and adherents, opinion leaders and townsfolks for sensitizing the people against cultural practices that promote poverty.
\end{abstract}

Keywords: Poverty, African Traditional Religion, Traditional leadership, Natural resources and Amansie West

(C) 2021 The Author(s). Published and Maintained by Noyam Publishers.

This is an open access article under the CCBY license (http://creativecommons.org/licenses/by/4.0/).

\section{INTRODUCTION}

Ghana, like many African countries, has issues of poverty and this is due to the economic hardship, issues of unemployment, the lack of opportunities among others, which have served as a driving force of most communities into poverty. The World Bank measures poverty based on the state of income and expenditure on consumption level, and considers a country to be poor if it falls below the "poverty line"1. With about 6.8 million people representing $22.7 \%$ of Ghana's population considered poor and 8.2 percent considered extremely poor, it reveals that the country still has issues of poverty to deal with. ${ }^{2}$ Even though the country attained middle-class status in 2010 and recorded an increase in per capita growth, economic inequality on livelihood is still on the rise and poverty remains prevalent in many areas. A major challenge is that most of these statistics are financially oriented with little or no social or cultural parameters

\footnotetext{
When estimating poverty worldwide, the same benchmark poverty line has to be used, and expressed in a common unit across countries. Therefore, for the purpose of global aggregation and comparison, the World Bank uses reference lines set at $\$ 1.25$ and $\$ 2$ per capita per day. Such a simple monetary approach to measuring poverty is widely used, for example in tracking progress towards the fulfilment of the Millennium Development Goals; Martin Ravallion, and Chen, S., "The developing world is poorer than we thought, but no less successful in the fight against poverty", Policy Research Working Paper Series, N0. 4703, The World Bank, 2008.

2 Ghana Statistical Service. Poverty Trends in Ghana 2005 - 2017, Ghana Living Standards Survey Round 7 (2018): 10
} 
which largely influence the state of poverty in Ghana and elsewhere. The Amansie West District is specifically located within latitude $6.05^{\circ}$ West: $6.35^{\circ}$ North: $1.40^{\circ}$ South and $2.05^{\circ}$ East serve as a regional boundary between Ashanti Region on one side and Central and Western Region on the other side. ${ }^{3}$ In the Amansie West Area which is a typical traditional setting, the definition and the perception of poverty is not only influenced by economic and financial factors but also socio-cultural and religious factors. With regards to the reports of ongoing environmental degradation in the community, it is clear that these perceptions have informed how some of the indigenes treat the natural environment. Based on this background, the study sought to investigate the Traditional Religious thoughts of the people and the impact this has had on the state of poverty and the livelihood of the people.

\section{THE CONCEPT OF POVERTY}

In examining the concept and issues of poverty, many streams of ideas have emerged to inform and shape these concepts. However, these ideas, although may have some commonalities, do not add up to a single coherent conceptual framework. Osmani states that a major theme underlying all these streams is diversity, thus the diversity of ways in which people perceive and experience poverty, diversity in how poor people attempt either to escape poverty or to cope with it, and diversity of policy interventions needed for contending poverty. ${ }^{4}$ These varied opinions should inform researchers about issues of poverty to enable them to approach the subject with a sense of acknowledging the relevance of diversity as they may influence the perception and definition of poverty.

Poverty as a human condition has different causal agents and these may range from economic, political, sociocultural and in some cases religious factors. However, Sen describes these agents as capability views of poverty, which can be understood as the lack of ability for people or society to live the kinds of life they value as compared with other concepts, such as utility. ${ }^{5}$ The problem with this statement is with the basic capabilities of poverty. Besides, if capabilities are defined solely in terms of individual or societal preferences then, to some degree, poverty is relative, and possibly, intrinsically multidimensional, which attests to definitional difficulties.

Some world institutional bodies have attempted to define poverty based on some causal factors of interest. According to the Human Development Report published for the United Nations Development Programme (UNDP), poverty means not being able to heat your home, pay your rent, or buy the essentials for your children. It means waking up every day facing insecurity, uncertainty, and impossible decisions about money. It means facing marginalisation and even discrimination - because of one's financial circumstances. The constant stress it causes can lead to problems that deprive people of the chance to play a full part in society. ${ }^{6}$

The level of direct financial resources and assets that people own or control seem to be the main determinants of what could be defined as being poor. ${ }^{7}$ However, recent studies outlined by Goulden et al, and Forsyth et al suggest that income-based definitions of poverty have been widely criticized as being too narrow as it has been contextually inappropriate for the developing countries. ${ }^{8}$ Clearly, the availability of financial resources, for instance, is not a solution to the spiritual or cultural needs of some rural folk. For Townsend, the approach to the definition of poverty should not be finance-related. Townsend neither describes poverty in the sense of lack, that is, failing to meet some particular needs nor measuring poverty solely in terms of income. ${ }^{9}$ For him, poverty is apparent when there is a failure to keep with the standards prevalent in a given society. It encompasses things other than strictly material needs. Such a standard of measurement is thoughtful enough and will serve as a relevant guide for answering questions such as, how does the analysis on religious thoughts and traditions affect the use of environment and poverty situation of the people?

There is no doubt, at all that, most definitions and descriptions of poverty have consistently measured poverty in financial terms hence, raising questions of its appropriateness. A good definition should not be narrow in scope which might demonstrate aptness only towards some societies like the developed countries, but inconsequential to the developing countries like Ghana. It must contrarily be stated that, in many African and Asian civilizations, not only has poverty been measured by the scale of material benefits or the lack of it, but also, by the extent of cultural and religious fulfilment. Any deprivation of a person's specific cultural or religious rites, such as the denial of one's custodian right, can be in the ordinary sense imply one's deficiency. Poverty, then, is not just when there is a lack of income, but also when there is no access to education, health, and a lack of prudent use of the natural resources in the environment.

\footnotetext{
Ministry of Food and Agriculture (2013). Amansie West, Republic of Ghana. Accessed November 20, 2017.http://mofa.gov.gh/site/amansie-west

Siddiqur Rahman Osmani, Evolving Views on Poverty Concept, Assessment and Strategy (Asia: Asian Development Bank Document, 2003 ): 1-8.

Amartya Sen, Commodities and Capabilities. (Amsterdam: North-Holland, 1985).

Human development Report Published for the United Nations Development Programme (UNDP) (New York: Oxford University Press, 1992).

These include: income (from employment, benefits, pension, interest on savings, gifts); financial assets (savings, a home); material goods (e.g. washing machine, car, computer).

8 Goulden Chris and Connor D'Arcy. A definition of Poverty. York: Joseph Rowntree Foundation. Accessed August 16, 2017. https://www.jrf.org.uk/report/definition-poverty; Tim Forsyth, M. Leach, and I. Scoones. Poverty and environment: priorities for research and policy, Prepared for the United Nations Development Programme and European Commission, (UK: Institute of Development Studies, 1998), $17-19$.

Peter Townsend, The Concept of Poverty. (London: Heinemann, 1979), 31.
} 


\section{RELIGIO-CULTURAL VIEW ON POVERTY IN AFRICA}

Generally, the imminence of poverty is a challenge to any society, and to their cultural identity in particular; nevertheless, religion provides a unique perspective to the phenomenon..$^{10}$ For instance, the African religious consciousness has a lot to offer in myths, stories, proverbs, and prohibitions which support, protect, or relieve the poor and the destitute from their plight. Regardless of this consciousness, it is surprising to note that a huge number of African countries remain poverty-stricken nations even though religion is flourishing within the continent. ${ }^{11}$ This notwithstanding Beyers contends that, religion has spiritual and moral resources which can alleviate societal poverty hence religion, can therefore, be a catalytic agent for addressing poverty in African communities. ${ }^{12}$

Even though poverty is a socio-economic challenge, in Africa, the religious belief systems and practices of the people which constitute the culture of the people cannot be side-lined. This supposes that religious sentiments of Africans do permeate their socio-cultural, political, and economic perspectives. And it links up with Sire's perspective on world-view which he says, is "a set of presuppositions which we hold about the basic make-up of our world, which influences our living"13 Therefore, in reflecting on the African religious world-view, it is important to assimilate the dynamic forces of cultural norms, values and practices, which are essentially life fundamentals.

Within the context of this discussion, the worldview of a people does not only inform their perceptions but more than that, it determines the kind of society they build. Mbiti is of the view that, when the African looks at his environment and everything in it (living and non-living), it stimulates them to reflect upon their life and the universe in which they lived. ${ }^{14}$ The result of this reflection is a gradual building up of the African views or ideas and the way Africans understand themselves and the world around them. ${ }^{15}$ However, the observation made is neither exclusive to Mbiti nor is it to the African; since, some Asian and European tribes have their worldview framed upon reflecting on nature.

African Traditional Religion stresses on the teachings of the importance and values of community and relationships. Through its teachings, Africans believe that poverty alleviation is a call unto an entire community and not a specific individual. This concept therefore breeds a sense of belonging among the people in finding a solution to their challenges. African Traditional Religion maintains the mind-set that 'real poverty results from the blockage of vital links. ${ }^{16}$ To Africans, dealing with poverty goes beyond partnering with other institutions to instill positive attitudes towards the concept of work among the people. The indigenous African Traditional Religious mindset defines poverty as not only an economic challenge but a situation that has moral and spiritual influence. This understanding stems from the belief that the ancestral world has the power to bless or curse an individual, thus making one rich or poor. The question of whether traditional African religious consciousness and practices have any hope for the poverty situation of the people seems relevant.

Like many other religious civilisations, African communities have definitions, stories, myths, and proverbs that depict both the meaning and implications of poverty. ${ }^{17}$ For instance, some animists believe that, famine, drought, and poverty exist as a result of unseen spiritual forces since, spiritual realities, for them, control the physical. They believe that, famine or hunger is caused by the gods who, they think, have been violated instead of, crediting an act of human negligence or perhaps, some bad environmental practices. Most tribal people of Africa believe that, it is God who gives and takes away life and material wealth. ${ }^{18}$ It is from this understanding that poverty is placed and analysed to determine the "creator-God" factor within the thinking of the societies. In most indigenous African communities, rainfall patterns are believed to be influenced by the gods instead of natural phenomenon. Some interpret the outbreak of some diseases with spiritual interpretations instead of examining the real causes. Again, in the African religious mind-set, some acknowledge poverty as the will of God, and some in other situations, considers it as a dreadful consequence of curses suffered when a deity is desecrated by an individual or a community.

In finding out whether these religious systems still prevail among some traditional communities, this study sets out to investigate religio-cultural thought on poverty and its impact on living standards in Amansie West District in Ghana.

\footnotetext{
10 Jaco Beyers, "The effect of religion on poverty", HTS Theological Studies 70(1), (2014): 1- 8.

11 In 2006, 34 of the 50 countries on the UN list of developed countries are in Africa. In many African countries, the Gross Domestic Product (GDP) per capita is less than US\$ 5200 per year, with the vast majority of the population living on much less.; Obaji Agbiji and I. Swart, Religion and Social transformation in Africa: a critical and appreciative perspective. Scriptura 1 no.114 (2015): 1-20.

12 Beyers, "The effect of religion on poverty", 6.

3 James Sire, The Universe Next Door. (Illinois: InterVarsity Press, 1988), 17.

4 John Mbiti, Introduction to African Religion. (London: Heinemann, 1975), 31.

Mbiti, Introduction to African Religion, 31.

16 Manci, Thembayona and Paulus Emmanuel, The Response To African Religion To Poverty, With Specific Reference To The Umzimkhulu Municipality, University of South Africa Pretoria, (2009) Accessed October 25, 2019 http://hdl.handle.net/10500/580

17 Agbiji and Swart, Religion and Social Transformation in Africa.

18 John Mbiti, Concepts of God in Africa. (U.K: Camelot Press Ltd., 1975), 83.
} 


\section{METHODOLOGY}

The focus of the methodology was structured to examine the religious response to the issues of poverty within the Amansie West District in Ghana and this could be found within the framework of empirical studies in Religious studies. The study used a mixed-method approach, with both qualitative and quantitative data obtained via interviews and questionnaires. The researcher utilized both primary and secondary sources of data. The primary sources explored information via interviews, semi-structured questionnaires, field data collection, and field observation. Also, published and unpublished works were explored, which served as a secondary source of data. In generating religio-cultural responses, fifty respondents were involved in the survey with respondents being residents in the community for over a decade. The purposive sampling procedure was also applied, since it ensured that, certain types of individuals or persons displaying certain attributes, knowledge or experience were included in the study. ${ }^{19}$ The traditional leaders (Chiefs, Queen-mothers and traditional council members) who possibly acted as gatekeepers were purposively targeted. This technique allowed information and data to be collected from indigenous people and key informants such as the District Chief Executive, the Police, the Environmental Protection Authority (EPA), Educationists, Pastors, the Member of Parliament and the Assemblymen. Furthermore, interviews conducted in the local dialogue with the indigenes for instance, tended to be at a high responsive rate and was able to draw-out in-depth information. Recorded information from interviews was transcribed and coded under the various themes for further analysis. Semi-structured interviews were used with well-defined questions and this inspired elaborate responses from interviewees. However, one-on-one sessions were scheduled with key individuals who had vital and detailed information to some of research questions and group discussions were also conducted for smaller groups and unions. Frequencies and percentages were employed in analysing the data obtained.

\section{FINDINGS AND DISCUSSIONS}

\section{The state of poverty and How poverty is defined and perceived in Amansie West Traditional}

The Amansie West community though blessed with abundant natural resources such as fertile lands for farming, mineral resources and forest reserves suffers greatly from poverty. Out of the total population of 134, 331 people, about $25 \%$ of the population in Amansie West District at the time of this research lived on US\$ 0.7 per day, which is considered within the extreme poverty category. ${ }^{20}$ The study revealed that the factors that contribute largely to issues of poverty in Amansie were; the state of unemployment, activities that lead to environmental degradation (illegal mining and illegal timber extraction); increase in the population growth due to the spate of high teenage pregnancies; lack of community support and the lack of interest in Agriculture, which serves as a great source of income. The state of poverty, according to $90 \%$ of respondents, had led to the abuse of the natural environment, and this confirms the World Commission on Environment and Development (WCED) findings that, the causes of the state of the global environment is strongly linked to poverty and other critical issues of development. ${ }^{21}$ Defining and measuring poverty according to many researchers have attracted a lot of attention in the last decade and beyond..$^{22}$ Acquiring information on how the people of Amansie West addressed poverty was of great interest to the study, hence the researchers asked respondents about their definition of poverty and the results given were categorized into these groups as shown in Table 1.

\begin{tabular}{|l|l|l|}
\hline Responses on the definition of poverty & Frequency & Percentages \\
\hline The lack of basic needs (food, clothing, housing) & 20 & 40 \\
\hline $\begin{array}{l}\text { The lack of certain commodities that are common in the society where you live } \\
\text { (farms, lands, etc.) }\end{array}$ & 14 & 28 \\
\hline The inability to purchase items due to the low-income ratio (income-based) & 9 & 18 \\
\hline $\begin{array}{l}\text { The inability to provide for your households due to a rise in price levels } \\
\text { (economic hike) }\end{array}$ & 7 & 14 \\
\hline
\end{tabular}

Source: Field Survey 2019

A majority of respondents defined poverty as the lack of basic needs for the survival of humans. This category saw poverty as an economic challenge and the lack of these basic needs inevitably meant poverty. However, the study discovered that the people of Amansie West had the belief contrary to the saying that money answers all things (c.f. Eccl 10:19) which meant that to them, the lack of money should not be the measure of poverty. As a typical traditional setting

19 Bruce Berg, Qualitative Research Methods for the Social Sciences. (New York: Pearson Educational Inc., 2007$), 44$.

20 Ministry of Food and Agriculture - Republic of Ghana, Report on Amansie West District. Retrieved from: http://mofa.gov.gh/site/amansie west: Cited on: 20th November 2017

21 United Nations (1987).”Report of the World Commission on Environment and Development: Our Common Future, from one Earth to one World." General Assembly Resolution 42/187. Accessed October 29, 2017. http://www.un.org/documents

22 Aldi Hagenaars and Klaas de Vos. The Definition and measurement of poverty. The Journal of Human Resources, 23 no. 2 , (1988): 211 - 221. Accessed April 25, 2020. http://www.jstor.org/stable/145776 
where Agriculture is the backbone of their local economy, the lack of commodities common to the average individual is deemed poverty. To them, it was the lack of land as property, the lack of farms for agricultural purposes, and the lack of family support that meant an individual was poor.

The varied opinions expressed above confirmed Chamber's admission that there has been ambiguity as to how the term 'poverty' is used. ${ }^{23}$ It is worth noting that the definition of poverty is highly contested by scholars and practitioners. These varying definitions of poverty from respondents meant their beliefs had been influenced with probably a perception or a degree of reality which could have been drawn from challenges and situations common to their area. Again, it is agreed that, setting crucial perimeters to help determine its very nature (i.e. whether economic, financial, social, or religious) have been debatable. ${ }^{24}$ Based on that, the researcher further asked respondents how poverty is perceived in their communities, the responses are given as shown in Table 2

\begin{tabular}{|l|l|l|}
\hline Responses & Frequency & Percentages \\
\hline Economic & 29 & 58 \\
\hline Spiritual & 14 & 28 \\
\hline Moral / Attitudinal & 7 & 14 \\
\hline
\end{tabular}

Source: Field survey, 2019

A majority of respondents saw poverty as an economic challenge which most expected the Central Government and leaders to address. This category believed that leadership in various forms ranging from political through to religious should provide the necessary guidelines towards easing the burden of the people. Economic indicators such as employment, education and provision of facilities were of great interest to this category. This notwithstanding, a section of the respondents strongly believed that poverty was a spiritual issue and this category reflected the typical traditional mind-set. To this group, the spiritual world and ancestors had the power to influence the financial state of an individual. Clearly, such thoughts could not have been discarded when working in a traditional setting, as from childhood a person's perception and their way of life may have been dictated by these traditional beliefs.

\section{Factors that influence the religio-cultural thoughts on poverty in Amansie}

The study area being a typical traditional setting, the people emphasized individual wellbeing which is common to their culture and practice. In investigating these religio-cultural thoughts, the study revealed that the community held some traditional and religious beliefs about poverty and these were largely captured by the following factors:

\section{Proverbial Sayings and Teachings that guided financial literacy and financial support}

In the religio-cultural understanding of the people of Amansie West district, the issue of poverty is variously perceived. Like many other religious civilizations, African communities have definitions, stories, myths, and proverbs that depict both the meaning and implications of poverty. ${ }^{25}$ The study observed that knowledge, traditions and beliefs of the people in Amansie West could not be entirely addressed without the issue of Akan sayings and proverbial material which have been infused into the fabric of their being. Proverbs, according to Agyekum, are concise sayings that embody general truths or principles and the way of life of a people..$^{26}$ For the poor, on the issues of poverty, many of these proverbial sayings instil peace, courage, hope, and some other virtues which can be personified as the cornerstone of human life realities. The study further established that, these proverbs directed to the poor were meant to inspire hard work, resistance to sluggishness, and to be part of the indigenous transformational educational system. These respondents mentioned that, wise sayings had been part of their childhood orientation and had ever been the unseen teacher and counsellor who assist in times of engaging in issues of prudent analysis. Since many young persons within the communities were being confronted with varied circumstances of needs and wants, which in some cases have required deeper reflections, these wise and proverbial sayings had offered free counselling services. Example of such proverbial sayings mentioned by Amoabeng Agyei which served as lessons to the poor was chia wo a, cnwu, wow nkwa a, wow adee. This literary meant "if you are poor do not die, for with life comes one's wealth" The lesson learned was that, whereas a person's state of poverty can be reversed with time, death on the other hand, could not be reversed.

\footnotetext{
23 Robert Chambers, "What is poverty? Who asks? Who answers?” In Poverty in focus: What is poverty? Concepts and Measures. UNDP, International Poverty Centre, 2006. Accessed March 17, 2019. http://www.undp-povertycentre.org/documents

24 Geoff Handley et al, Poverty and Poverty Reduction in Sub-Saharan Africa: An Overview of Key Issues. Overseas Development Institute, Working Paper 299 2009:1-2.

25 Agbiji and Swart, Religion and Social Transformation in Africa: A critical and appreciative perspective. Scriptura 1 no.114 (2015), Pp. 1-20.

26 Kofi Agyekum, “The Ethnosemantics and Proverbs of ohia, “poverty” in Akan” Legon Journal of the Humanities 28.2 (2017): 23 - 48.
} 


\section{The spiritual dimension of poverty as seen by the people}

A good percentage of the people in Amansie West, specifically the traditional indigenes believed that poverty has a spiritual dimension; to them, poverty was an artwork of some spiritual forces. This belief to them were not stories that made up folktales but were seen in some members and families within the community. Whereas some had considered it as an act of a spell cast, others however understood it as a transgenerational curse on such individuals or families. In the African traditional setting, some strongly believe that poverty could be inflicted through witcheraft, traditional priest or shrines, and for some, direct curse through destructive prayers or incantation. Even though some people in the communities believed the existence of heaven, the traditional religious adherents strongly believed in the power of the ancestral world. A great section admitted that the ancestral world had the power to make a person rich or poor. These people believed the ancestors have what it takes to aid the living with material and spiritual needs. These bold claims were as a result of the ability of some of the interviewee's to cite some examples, stories and occurrences as proof to their beliefs. From another perspective, some scholars have considered fatalism (i.e. bad luck) as that which is in part a consequence of the growing uncertainty and risk which has become an important factor of modern societies. ${ }^{27}$ The risk of one being confronted with events of bad luck cannot be overemphasized in the Amansie communities where overwhelming incidents, accidents and natural occurrences had been attributed to mere fatalism or spirituality.

\section{Support for the poor}

In dealing with issues of poverty in a traditional setting, it is generally believed that support for members is relatively high because of the nature of the family system which exists and also serves as a basic unit of society. When the survey assessed the perspective of the people on how the poor were being supported in the communities, it was discovered that the poor, unlike time past, were marginalised and mockingly excluded in some social decisions and events. It was further observed that, many poor persons struggle to survive and unfortunately, the social support system that in the past ensured that the underprivileged were catered for had all vanished into oblivion. Although some people admitted that the poor in the community have their daily sustenance provided for by family members, this support had never been enough. The survey revealed that some families had remotely expressed their support and care for their needy members, however, the extent of such compassion was losing its communal spirit and enthusiasm in the current dispensation. Individuals in this era are more concerned about their nuclear families as against the traditional extended family system. The fear this raises is the expectation that with the current conditions, there would be an exponential growth in the number of abandoned poor cases in the district. Ironically, it was observed that though less care was being given to the poor persons in the communities, families had given more attention and financial assistance to funerals, which have become an expensive venture in the current Ghanaian community. Projecting the present poverty situation for the poor in Amansie and some Ghanaian communities, raises the concern of social pessimism and a gloomy situation for the poor, if nothing is done. All these beliefs according to the people communicate a degree of responsibility to the traditional overlords. They are therefore expected to relate cordially with the living and watch over their interest or risk the chance of being punished in the Ancestral world by Amokye- an Akan deity assigned for such purpose.

\section{The impact of the perception of poverty on the lives of the people}

The study sought to know if the definitions, perception and religious beliefs of the people in poverty had affected their way of life and poverty issues in the community. Therefore, when the question was asked about how these perceptions on poverty have affected their everyday life, the responses given are shown in Table 3

\begin{tabular}{|l|l|l|}
\hline Responses & Frequency & Percentage \\
\hline Highly Affected/Influenced & 31 & 62 \\
\hline Moderately affected & 13 & 26 \\
\hline Not affected & 6 & 12 \\
\hline
\end{tabular}

Source: Field Survey 2019

The majority of respondents mentioned that the lives of the people of Amansie West had been highly influenced by their perception of poverty. Reports from the community revealed that environmental degradation in Amansie West District was high and culprits involved in such activities were largely people who saw poverty as an economic challenge. To this category, financial challenges coupled with economic challenges such as unemployment had forced people to apply dubious means to acquire financial freedom. Illegal mining operations, buying and selling of gold minerals without licenses and timber extraction among others had been the norm of the day. On the issue of immorality, some

\footnotetext{
27 Svetlana Stephenson, Public beliefs in the causes of wealth and poverty and legitimization of inequalities in Russia and Estonia. Social Justice Research 13(2), (2000): 83-100.
} 
young teenagers are engaged in social vices which had resulted in a higher rate of teenage pregnancies and abortion in Amansie West. ${ }^{28}$ The implications of some these challenges had become very detrimental on the finances of the people especially the poor in the society. Those who saw the issues of poverty as a spiritual challenge had resulted to engaging in prayers and hard work. This, they believe is the only possible solution to overturning poverty as a spiritual misfortune. Regardless of the responses given to support the high impact of these perceptions, some still maintained that the lifestyle of the people was partially affected by their perceptions of poverty. They stated that there was a general financial and economic challenge nationwide and this had made financial issues a challenge to reckon with.

\section{RECOMMENDATIONS}

The following recommendation is proposed from the issues emerging from the studies:

There is the need for Religio-Cultural Renaissance: The dynamism of culture, good as it might appear, should not undermine the very instincts that form the bloodstream of the community. Many religio-cultural beliefs and practices are being confronted by the upsurge of modernisation, secularisation, and diverse religious doctrines which in effect have impacted on most communal lives in Ghana. Cultural abuses which were dreaded for the reason of spiritual retribution have presently been frowned upon with impunity by residents of Amansie West district. To this end, the reinforcement of religio-cultural practices that had in the past inspired the promotion of values, adherence to prohibitions and myths in the social life of the people, should strongly be revitalised by the traditional authorities and be embraced by society.

\section{CONCLUSION}

In Amansie West traditional area, religion appears as a driving force, so relevant that it in some way regulates their socio-economic analysis of life and their very existence. Although the people are blessed with a variety of minerals and natural resources, the poverty incident somehow appears real and higher than the Ashanti Regional average of 23.4 percent. This study, therefore, examined the indigenous religious thoughts and the impact this thoughts have had on the wellbeing and the livelihood of the people of Amansie West. The study discovered that, amongst the factors that contributed to matters of poverty in Amansie were issues of unemployment, environmental degradation activities (especially illegal Mining), and the lack of interest in Agricultural activities. It was further revealed that, the lack of arable land for farming activities and reserved land as property among others meant that an individual was poor. Again, a majority of respondents saw poverty as an economic challenge, whereas others considered poverty as a spiritual or moral issue. This paper further revealed some factors that had influenced the religio-cultural thoughts on poverty in Amansie: Proverbial Sayings and Teachings that guided financial literacy and financial support; The spiritual dimension of poverty as understood by the people; and the support for the poor members of the community as had been required by the traditional ethos.

\section{ABOUT AUTHOR}

Charles Owusu Ampofo is an ordained minister of the Ghana Baptist Convention and is currently serving at the Victory Baptist Church, Kumasi-Ghana. Presently, he is the sitting president of the Baptist Ministers' Conference and has in the past lectured at the Baptist Theological Seminary. He is currently a PhD candidate in the Department of Religious Studies (KNUST), and holds a PGDE (UCC), MA. (ACT-Australia), and MPhil. (KNUST). He has research interests in exploring relationships between religion and environment, and religion and poverty.

\section{BIBLIOGRAPHY}

Agbiji, Obaji and Swart Ignatius, Religion and Social Transformation in Africa: A critical and appreciative perspective. Scriptura 114 (2015:1): 1-20.

Agyekum, Kofi. “The Ethnosemantics and Proverbs of ohia, "poverty" in Akan” Legon Journal of the Humanities 28.2 (2017): $23-48$.

Berg, Bruce Qualitative Research Methods for the Social Sciences. (New York: Pearson Educational Inc., 2007): 44.

Beyers, Jaco "The effect of religion on poverty", HTS Theological Studies 70(1), Art. \#2614, (2014): 1- 8.

Dorbbin, Dominic. "3,000 Teenager impregnated in Amansie West District" Peace FM, February 9, 2015. Accessed February 9, 2020. https://www.peacefmonline.com/pages/local/social/201502/231705.php.

Goulden, Chris, and Conor D'Arcy. 2014. A Definition of Poverty. York: Joseph Rowntree Foundation. Accessed August 16, 2017 https://www.jrf.org.uk/report/definition-poverty.

\footnotetext{
$\overline{28}$ Peacefmonline, 3,000 Teenagers impregnated in Amansie West District, https://www.peacefmonline.com Accessed February 9, 2020.
} 
Forsyth, Tim., Leach, M., \& Scoones I. Poverty and environment: priorities for research and policy (Prepared for the United Nations Development Programme and European Commission). (UK: Institute of Development Studies, 1998): 17-19.

Ghana Statistical Service. Poverty Trends in Ghana 2005 - 2017, Ghana Living Standards Survey Round 7 (2018): 10 Hagenaars, Aldi \& Klaas de Vos. "The Definition and measurement of poverty." Journal of Human Resources, 23(2), (1988): 211 - 221. Accessed April 25, 2020. http://www.jstor.org/stable/145776

Handley, Geoff., Higgins, Kate., Sharma, Bhavna., Bird, Kate. \& Cammack Diana. Poverty and Poverty Reduction in Sub-Saharan Africa: An Overview of Key Issues. Overseas

Development Institute, Working Paper 299 (2009):1-2.

Manci,Thembayona Paulus Emmanuel. "The response to African religion to poverty, with specific reference to the Umzimkhulu Municipality", University of South Africa Pretoria (2009). http://hdl.handle.net/10500/580

Mbiti, John. Concepts of God in Africa. (U.K: Camelot Press Ltd., 1975): 83.

Mbiti, John. Introduction to African Religion. (London: Heinemann, 1975): 31.

Ministry of Food and Agriculture - Republic of Ghana, Report on Amansie West District. Accessed November 20, 2017. http://mofa.gov.gh/site/amansie west.

Osmani, Siddiqur Rahman. Evolving Views on Poverty Concept, Assessment and Strategy (Asia: Asian Development Bank Document 2003): 1-8.

Poverty in Africa, Accessed February 22, 2020. http://wkikpedia.org/LDC's list.un.org

Ravallion, Martin \& Chen, S., "The developing world is poorer than we thought, but no less successful in the fight against poverty", Policy Research Working Paper Series, N0. 4703, The World Bank, (2008).

Robert Chambers, "What is poverty? Who asks? Who answers?" In Poverty in focus: What is poverty? Concepts and Measures. UNDP, International Poverty Centre, 2006. Accessed March 17, 2019. http://www.undp-povertycentre.org/documents.

Sen, Amartya. Commodities and Capabilities. (Amsterdam: North-Holland, 1985).

Sire, James. The universe next door. (Illinois: InterVarsity Press, 1988): 17.

Stephenson, Svetlana. "Public beliefs in the causes of wealth and poverty and legitimization of inequalities in Russia and Estonia" Social Justice Research 13(2), 83-100.

Townsend, Peter. The Concept of Poverty. (London: Heinemann, 1979): 31.

United Nations "Report of the World Commission on Environment and Development: Our Common Future, from one Earth to one World." General Assembly Resolution 42/187 (1987)."Accessed October 29, 2017. https://sustainabledevelopment.un.org/content/documents/5987our-common-future.pdf

United Nations Development Programme (UNDP). Human Development Report (New York: Oxford Oxford University Press, 1992). 